\title{
Analysis of Treatment Outcome Associated with Pre-Operative Diagnostic Accuracy Changes and Dental Treatment Timing in Odontogenic Sinusitis Involving Unilateral Maxillary Sinus
}

\author{
Ki-Yong Choi, Ji-Hun Mo, and Young-Jun Chung ${ }^{(D)}$ \\ Department of Otorhinolaryngology-Head and Neck Surgery, Dankook University College of Medicine, Cheonan, Korea
}

편측 상악동을 침범한 치성 부비동염의 수술 전 진단 정확도 변화 및 치아 치료 시기에 따른 치료 성적 분석

최기용·모지훈·정영준

단국대학교 의과대학 이비인후-두경부외과학교실

\author{
Received October 9, 2018 \\ Revised March 20,2019 \\ Accepted April 5, 2019 \\ Address for correspondence \\ Young-Jun Chung, MD \\ Department of Otorhinolaryngology- \\ Head and Neck Surgery, \\ Dankook University \\ College of Medicine, \\ 201 Manghyang-ro, Dongnam-gu, \\ Cheonan 31116, Korea \\ Tel $+82-41-550-3974$ \\ Fax $+82-41-556-1090$ \\ E-mail entdocjung@daum.net
}

Background and Objectives Unilateral sinusitis is caused by various factors. Odontogenic sinusitis; especially, is different from non-odontogenic sinusitis in clinical features and prognosis. The purpose of this study is to evaluate the prognosis of odontogenic sinusitis in accordance with the changes in diagnostic accuracy over time and the timing of dental treatment. Subjects and Method 195 patients who underwent endoscopic sinus surgery for unilateral sinusitis within the interval from 2006 to 2017 were reviewed to analyze the etiologies and clinical characteristics. Preoperative CT was assessed to identify patients who had not been diagnosed with odontogenic sinusitis in the past. In the unilateral bacterial sinusitis, we identified changes in incidence, diagnostic accuracy, and outcome in the odontogenic sinusitis. We divided odontogenic sinusitis patients into three groups: preoperative and intraoperative dental treatment group, postoperative dental treatment group, and untreated group. Then we analyzed the difference in prognosis of these three groups.

Results The total number of patients with odontogenic sinusitis was 86 (44\%), which accounted for about $36 \%$ until 2011, but increased to about 48\% after 2013. From 2006 to 2011, there were 15 cases of missed diagnosis of odontogenic sinusitis, but there was 1 case in 2012 and no cases since 2013. The treatment outcome of unilateral bacterial sinusitis was significantly increased from $84.1 \%$ before 2011 to $96 \%$ after 2012 . The success rate was $97.1 \%$ in the case of accurate diagnosis of odontogenic sinusitis, but the success rate was $43.8 \%$ in case of missed diagnosis. In odontogenic sinusitis, the success rate was low when dental treatment was not performed. However, there was no difference in success rate among different dental treatment timings.

Conclusion The incidence of odontogenic sinusitis has steadily increased over the last decade. The prognosis has been improved by appropriate treatment under accurate diagnosis through preoperative examination and radiological evaluation. There was no difference in the prognosis of odontogenic sinusitis according to the dental treatment time. Therefore, it is a good choice for tooth preservation to have an endoscopic sinus surgery first and then decide the dental treatment timing. Korean J Otorhinolaryngol-Head Neck Surg 2019;62(11):624-30

Key Words Chronic rhinosinusitis · Odontogenic sinusitis · Treatment strategy.

This is an Open Access article distributed under the terms of the Creative Commons Attribution Non-Commercial License (https://creativecommons.org/licenses/by-nc/4.0) which permits unrestricted non-commercial use, distribution, and reproduction in any medium, provided the original work is properly cited. 


\section{서 론}

부비동 병변은 양측성으로 발생하는 경우가 대부분이며 편측에 국한하여 발생하는 경우는 $2.5 \%$ 에서 $23.1 \%$ 의 빈도로 보고되고 있다. ${ }^{1-4)}$ 편측성 부비동염은 악성 종양, 진균성 부 비동염, 낭종 그리고 치성 부비동염 등을 감별해야 하는 질환 이다. 과거에는 편측성 부비동염에서 치성 부비동염이 차지 하는 비율이 $10 \%$ 정도로 알려졌지만, 최근에는 $40 \%$ 까지 증 가했다는 보고가 있다. ${ }^{5-10)}$ 특히 전산화단층촬영(CT) 영상 검사를 포함한 최근 연구에서는 편측성 부비동염의 $70 \%$ 에서 치성 부비동염이 확인되었다는 결과도 보고된 바 있다. ${ }^{11,2)}$ 이 러한 변화는 인구의 고령화 및 구강 보건에 대한 인식의 변화, 치과 치료 및 임플란트 시술의 증가 등으로 치성 부비동염의 발생률이 같이 증가하고 있다는 것을 반영한다. 또한, 과거에 는 치성 부비동염에 대한 인식이 부족하여 환자 진료 시에 문 진과 전산화단층촬영 영상에서 진단을 놓친 사례도 많았을 것으로 생각된다. ${ }^{12,13)}$ 부비동염의 치료에 있어 항생제 및 스테 로이드 치료, 그리고 부비동 내시경 수술로 좋은 결과를 얻을 수 있지만 치성 원인에 의한 부비동염에서는 충분하지 않을 수 있다. 치성 부비동염은 내과적, 외과적 치료뿐만 아니라 치 과 치료를 같이 병행해야 완치율이 높기에 수술 전 정확한 진 단이 필요한 질환이다. 이에 저자들은 최근 10 년간 상악동을 침범한 편측성 세균성 부비동염을 분석하여 치성 부비동염의 발생 변화와 이에 따른 예후의 변화를 분석해보고자 하였다.

\section{대상 및 방법}

2006년 1월부터 2017년 7월까지 단국대학교병원 이비인후 과에서 편측성 부비동 질환으로 부비동 내시경 수술을 받았 던 환자 중 종양, 진균성 부비동염, 상악동 점액낭종 등을 제 외한 상악동을 침범한 편측성 세균성 부비동염 소견을 보인 195 명 환자의 의무기록을 후향적으로 분석하였다. 본 연구는 '헬싱키 선언(declaration of Helsinki)'을 준수하였으며, 단국 대학교병원 연구 윤리 심의 위원회의 승인을 받고 진행되었다 (IRB. No. 2019-04-010-001). 모든 환자는 수술 전 전산화 단층촬영 영상을 시행하였으며 외래 및 입원, 수술기록지와 환자의 나이, 과거력, 성별, 기저 질환 및 비용종 동반 유무를 확인하여 임상 양상을 분석하였다. 그리고 첫 진료 시 시행 한 설문조사를 이용하여 환자가 호소하는 증상을 확인하였 다. 환자들은 수술 전 2주에서 4주까지 항생제를 사용하였고 호전 정도를 확인한 뒤에 수술을 진행하였다. 수술 이후 항생 제는 모든 환자에게 1 2주 처방하여 사용하였으며 스테로이 드는 사용하지 않았다. 치성 부비동염 환자군은 처음 본원에
내원하였을 당시 임상 양상과 컴퓨터단층촬영으로 치성 부 비동염을 정확히 진단을 내렸던 환자들과 추가로 초기엔 단 순 편측성 부비동염 이라고 진단내렸던 환자들 중 의무기록 과 전산화단층촬영 영상을 다시 분석해 추후에 치성 부비동 염으로 진단을 내린 환자들을 추가하여 총 치성 부비동염 환 자의 수를 구하였다. 치성 부비동염 진단은 전산화단층촬영 영상에서 상악 치조골(maxillary alveolar bone)에 결손이 있어 구강과 연결되는 구강상악동루(oroantral fistula), 임플 란트의 상악동 합입과 동반된 부비동염 소견, 치조백선(lamina dura)의 소실 소견과 치근 주위의 연부 조직 음영이 보이 는 치근단 농양(periapical abscess)과 같은 치성 부비동염 소 견을 두 명의 의사가 독립적으로 판정한 후에 판정의 불일치 가 있는 경우는 나중에 합의하여 판정하였다. 이를 토대로 치 성 부비동염의 진단율을 확인하였으며, 총 편측성 세균성 부 비동염 환자에서 치성 부비동염이 차지하는 비율과 진단 정 확도를 연도별로 확인하였다. 모든 환자는 수술 후 최소 3 개 월 이상 외래 경과 관찰을 하였으며 수술 후 3 개월째 외래 내 원 시 시행한 비내시경 소견을 분석하였다. Lund-Kennedy scoring system에 따라 비분비물, 부종, 비용종과 같은 병적 인 증거가 하나라도 있는 경우는 수술 후 경과가 나쁜 군으 로 분류하였으며, 이러한 병적인 증거가 하나도 없는 경우는 경과가 좋은 군으로 분류하였다. 그리고 치성 부비동염 환자 들을 대상으로 치과 치료 시행 유무와 받은 시점을 차트를 통 해 확인하였다. 이를 통해 총 치성 부비동염 환자를 수술 전 에 치과 치료를 받거나 수술 시에 치과 치료를 동시에 받았 던 군, 부비동 내시경 수술을 한 이후에 치과 치료를 받았던 군, 그리고 치과 치료를 받지 않은 군까지 총 3 군으로 나누어 환자의 치료 성적을 비교하였다.

\section{통계 분석}

통계 분석은 SPSS version 20(IBM Corp., Armonk, NY, USA)을 이용하였다. 각 질환 간의 유의한 비교 인자를 파악 하기 위해 일원 배치 분산분석(one-way analysis of variance)을 이용한 후 사후 검정을 추가하였다. 빈도 비교의 경 우에는 chi-square test를 사용하였다. $p$ 값이 0.05 이하인 경 우를 의미있는 차이가 있다고 판단하였다.

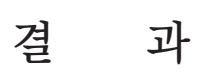

\section{치성 부비동염과 비치성 부비동염에서의 임상 양상}

편측성 세균성 부비동염으로 진단받은 195 명 환자 중 비 치성(non-odontogenic) 부비동염군은 109명이었으며, 치성 (odontogenic) 부비동염군은 86명이었다. 평균 나이는 비치성 
부비동염군은 40.63세이었으며 치성 부비동염군은 52.7세로 치성 부비동염군이 유의하게 평균 연령이 높았으며, 비용종 동반 유무는 비치성 부비동염군이 $41.3 \%$, 치성 부비동염군은 $26.7 \%$ 로 치성 부비동염에서 비용종이 동반되는 경우가 유의 하게 적었다. 두 군에서 혈압, 당뇨, 흡연 유무 그리고 성비의 유의한 차이는 없었다(Table 1).

첫 진료 시 환자들이 작성한 설문조사를 이용하여 비폐 색, 후비루, 화농성 비루, 안면통, 안면부 압박감, 악취, 두통, 후각 저하 총 8 가지 증상의 유무를 확인하였다. 비치성 부비 동염군에서는 비폐색 및 후각 저하를 유의하게 더 호소하였 으며, 치성 부비동염군에서는 악취를 유의하게 더 호소하였 다. 그 외의 증상에서는 두 군 사이에 유의한 차이는 없었다 (Table 2).

편측성 부비동염 환자군을 2011년 이전, 2012년 이후 두 군으로 나누어 환자의 성별 및 연령의 변화를 확인하였다. 비 치성 부비동염과 치성 부비동염 모두 남자가 여자보다 높은 비율을 보였고, 평균 연령은 2011년 이전은 비치성 부비동염 군이 34.8세, 치성 부비동염군은 47.8세였으며, 2012년 이후 로는 비치성 부비동염 군은 44.6세, 치성 부비동염군은 54.7 세로 2012년 이후 편측성 세균성 부비동염으로 내원한 환자 가 고령화된 소견을 보였다. 2011년 이전, 2012년 이후 모든 기간에서 치성 부비동염군이 비치성 부비동염군보다 평균 연

Table 1. Comparison of non-odontogenic sinusitis and odontogenic sinusitis

\begin{tabular}{lccc}
\hline & $\begin{array}{c}\text { Non-odonto } \\
(\mathrm{n}=109)\end{array}$ & $\begin{array}{c}\text { Odonto } \\
(\mathrm{n}=86)\end{array}$ & p-value \\
\hline Age & $40.63 \pm 19.3$ & $52.70 \pm 14.5$ & 0.001 \\
Polyp (+, \%) & $45(41.3)$ & $23(26.7)$ & 0.034 \\
Hypertension (\%) & $22(20.2)$ & $22(25.6)$ & 0.371 \\
Diabetes mellitus (\%) & $12(11)$ & $16(18.6)$ & 0.133 \\
Smoking (\%) & $33(30.3)$ & $28(32.6)$ & 0.907 \\
Sex (M:F) & $77: 32$ & $50: 36$ & 0.069 \\
\hline
\end{tabular}

Odonto: odontogenic, M: male, F: female

Table 2. Presenting symptoms of non-odontogenic sinusitis and odontogenic sinusitis

\begin{tabular}{lccc}
\hline & $\begin{array}{c}\text { Non-odonto } \\
(\mathrm{n}=109, \%)\end{array}$ & $\begin{array}{c}\text { Odonto } \\
(\mathrm{n}=86, \%)\end{array}$ & p-value \\
\hline Nasal obstruction & $76(69.7)$ & $43(50.0)$ & 0.005 \\
Postnasal drip & $53(48.6)$ & $46(53.5)$ & 0.500 \\
Purulent rhinorrhea & $53(48.6)$ & $43(50.0)$ & 0.849 \\
Cheek pain & $11(10.1)$ & $6(7.0)$ & 0.444 \\
Cheek swelling & $3(2.8)$ & $7(8.1)$ & 0.090 \\
Foul odor & $17(15.6)$ & $38(44.2)$ & 0.001 \\
Headache & $27(24.8)$ & $26(30.2)$ & 0.395 \\
Hyposmia & $29(26.6)$ & $12(14.0)$ & 0.031 \\
\hline
\end{tabular}

Odonto: odontogenic
령은 유의하게 높았다(Table 3).

\section{시간에 따른 진단 정확도의 변화와 그에 따른 치료 성적 의 변화}

2006년부터 2017년까지 편측성 세균성 부비동염 환자들 의 연도별 진단 정확도를 분석해 보면 치성 부비동염으로 진 단받은 환자는 매년 증가하는 추세를 보이고 있고 치성 부비 동염 진단을 놓친 경우는 2011년 이전에는 매년 2 3건 있었 으나 2012년은 1건이었으며 2013년 이후로는 진단을 놓친 경 우가 없었다. 치성 부비동염의 유병률은 연도별로 차이는 있 으나 점차 증가하는 추세를 보였다. 치료 성적은 2006년부터 2011년도까지는 84.1\%이었던 것에 비하여 2012년 이후로는 $96.0 \%$ 으로 유의하게 좋아지는 소견을 보였다(Table 4, Fig. 1).

편측성 세균성 부비동염 환자를 2011년 이전, 2012년 이후 두 군으로 나누어 치성 부비동염의 유병률을 확인하였으며 유병률은 $36.2 \%$ 에서 $48.4 \%$ 으로 증가하는 소견을 보였다. 두 군에서 비치성 부비동염 환자와 치성 부비동염 환자의 예후 를 비교하였을 때, 2012년 이후에는 비치성 부비동염 및 치성 부비동염 환자군에서 불량한 예후를 보인 경우는 각각 $2.4 \%$, $3.3 \%$ 로 적었다. 2011년 이전에는 비치성 부비동염 환자군에 서 불량한 예후를 보인 경우는 $4.5 \%$ 로 적었지만, 치성 부비 동염 환자군에서는 $20.5 \%$ (9명)에서 불량한 예후를 보였다 (Table 5).

치성 부비동염의 예후가 수술 당시의 진단 정확도와 관련 성이 있는지 확인하기 위해서 86명의 치성 부비동염 환자를 수술 당시에 정확한 진단을 내린 70 명과 진단을 놓친 16명 두 군으로 나누어 예후를 비교해 보았다. 치성 부비동염으로 진 단을 정확히 내렸던 70명에서는 $97.1 \%$ 의 좋은 예후를 보였으 며, 반면에 진단을 놓친 16명에서는 9명이 예후가 좋지 않아 43.8\%의 예후를 보여 의미있는 차이가 관찰되었다(Table 6).

\section{전산화단층촬영 소견에 따른 치성 부비동염의 치료 성적 차이}

치성 부비동염 환자를 수술 전에 시행한 CT 소견에 따라

Table 3. Characteristics of patients diagnosed with unilateral sinusitis before and after 2012

\begin{tabular}{llcc}
\hline & $M: F$ & Age & $p$-value \\
\hline 2006-2011 $(n=69)$ & & \multicolumn{3}{c}{0.002} \\
Non-odonto $(n=44)$ & $34: 10$ & $34.8 \pm 17.1$ & \\
Odonto $(n=25)$ & $16: 9$ & $47.8 \pm 14.5$ & \\
$2012-2017(n=126)$ & & & 0.001 \\
Non-odonto $(n=65)$ & $43: 22$ & $44.6 \pm 19.8$ & \\
Odonto $(n=61)$ & $34: 27$ & $54.7 \pm 14.1$ & \\
\hline Odonto: odontogenic, M: male, F: female &
\end{tabular}


Table 4. Diagnostic trend and treatment outcome of unilateral bacterial sinusitis

\begin{tabular}{|c|c|c|c|c|c|c|}
\hline Year & Unilateral sinusitis & $\begin{array}{c}\text { Preoperative } \\
\text { diagnosed (OMS) }\end{array}$ & $\begin{array}{c}\text { Diagnostic } \\
\text { missed (OMS) }\end{array}$ & OMS/total (\%) & Poor outcome (n) & $\begin{array}{c}\text { Treatment } \\
\text { outcome (\%) }\end{array}$ \\
\hline 2006 & 7 & 0 & 2 & 29 & 1 & 86 \\
\hline 2007 & 16 & 0 & 3 & 19 & 2 & 89 \\
\hline 2008 & 10 & 1 & 3 & 40 & 2 & 80 \\
\hline 2009 & 8 & 0 & 3 & 38 & 2 & 63 \\
\hline 2010 & 15 & 8 & 2 & 47 & 1 & 93 \\
\hline 2011 & 13 & 4 & 2 & 46 & 3 & 77 \\
\hline 2012 & 21 & 5 & 1 & 29 & 1 & 90 \\
\hline 2013 & 19 & 11 & 0 & 58 & 0 & 100 \\
\hline 2014 & 18 & 7 & 0 & 39 & 0 & 100 \\
\hline 2015 & 23 & 12 & 0 & 52 & 0 & 100 \\
\hline 2016 & 20 & 12 & 0 & 60 & 2 & 90 \\
\hline 2017 & 25 & 13 & 0 & 52 & 2 & 92 \\
\hline Total & 195 & 70 & 16 & 44.1 & 16 & 91.8 \\
\hline
\end{tabular}

OMS: odontogenic maxillary sinusitis

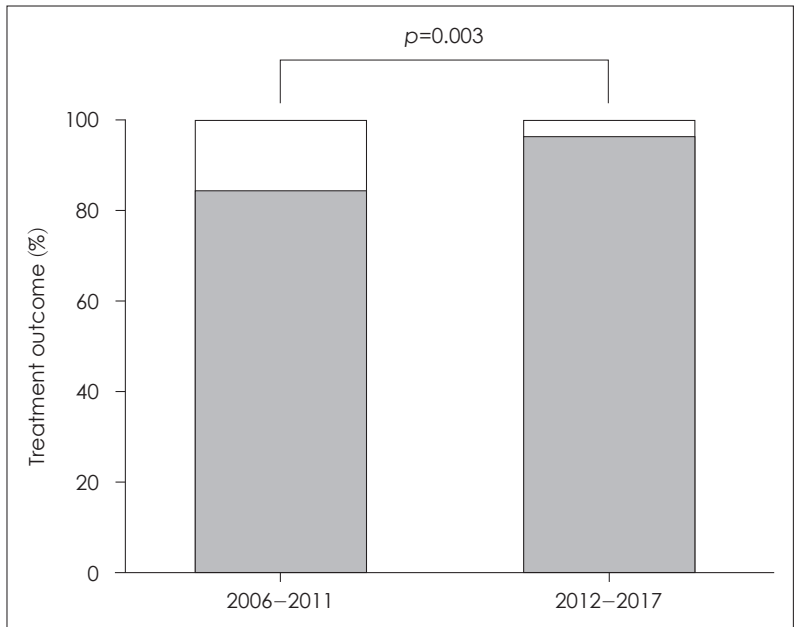

Fig. 1. Diagnostic trend and treatment outcome of unilateral bacterial sinusitis. There is a significant difference between the two groups. From 2012 to 2017 the group had a significantly higher treatment outcome than the 2006 to 2011 group (independent t-test: $p<0.05$ ).

치근단 농양, 임플란트, 그리고 구강상악동루 총 3군으로 나 누어 각 군의 치료 성적을 비교해 보았다. 치근단 농양이 관 찰된 환자는 56명이였으며 이 중 불량한 예후를 보인 경우는 10 명이었다. 임플란트군은 18 명이며 이 중 불량한 예후를 보 인 경우는 없었다. 구강상악동루 소견이 관찰된 환자는 12명 이었으며 이 중 1명이 불량한 예후를 보였다(Table 7).

\section{치성 부비동염에서 치과 치료 시점에 따른 치료 성적의 차이}

치성 부비동염 환자들 중 예후가 불량한 환자가 많았던 치 근단 농양군을 대상으로 치과 치료 시기 및 치료 유무에 따른 예후에 차이가 있는지 확인하기 위하여 치근단 농양 환자를
1) 치과 치료를 수술 전이나 수술 중에 받은 군, 2) 치과 치료 를 수술 후에 받은 군, 3) 치과 치료를 받지 않은 군 총 세 군 으로 분류하여 치료 성적을 비교해 보았다. 치과 치료를 수 술 전 이나 수술 당시에 받았던 군의 치료 성적은 $92.9 \%$, 치과 치료를 수술 이후에 받은 군의 치료 성적은 88.5\%로 두 군 모 두 양호한 치료 성적을 보였고 이 두 군 사이에서는 유의한 차 이는 없었으나 $(p=0.658)$ 치과 치료를 받지 않는 군은 $62.5 \%$ 로 치과 치료를 시행한 다른 두 군에 비하여 유의하게 낮은 치료 성적을 보였다( $p=0.05, p=0.046$ )(Fig. 2).

\section{고 찰}

만성 세균성 부비동염은 개구비도단위(ostiomeatal unit) 의 폐쇄, 환기 장애와 점액 저류, 점액 섬모 기능 저하 및 혐 기성 환경, 감염 및 면역 기능 장애 등이 병인으로 알려져 있 다. ${ }^{14)}$ 이에 반해 치성 부비동염은 해부학적으로 치과적인 질 환이 부비동으로 파급되는 것으로 침습적인 치과 시술, 상악 동 점막(schneiderian membrance)을 침범한 치주 질환 또 는 치성 농양에 의해 발병한다. ${ }^{6,15-17)}$ 치아 우식증과 같은 염 증성 질환이 치근염과 치수염을 일으키고 상악동막으로 염 증이 파급되어 상악동 내의 점액 섬모 기능을 변화시키게 된 다. 점액 섬모 기능의 손상으로 인하여 점액 전달과 점막 방 어에 문제가 생기고 개구부(ostium) 폐쇄가 생기며 박테리아 감염과 염증이 파급되어 치성 부비동염이 발생하게 된다. 상 악동과 치근 사이 거리는 $2.0 \mathrm{~mm}$ 정도로 가깝지만 단단한 피 질골로 이루어져 있기 때문에 실제로는 쉽게 염증이 파급되 지는 않는다. 하지만 임플란트 및 발치와 같은 시술 중에 손 상되는 경우에 치성 부비동염이 발생할 가능성이 높아진다 
Table 5. Changes in incidence and prognosis of unilateral sinusitis

\begin{tabular}{cccccccc}
\hline \multirow{2}{*}{ Group } & \multirow{2}{*}{ Total case } & \multirow{2}{*}{ Non-odonto } & Odonto, $\mathrm{n}(\%)$ & \multicolumn{3}{c}{ Poor outcome } \\
\cline { 6 - 8 } & & & & Total & Non-odonto, $\mathrm{n}(\%)$ & Odonto, $\mathrm{n}(\%)$ \\
\hline $2006-2011$ & 69 & 44 & $25(36.2)$ & 11 & $2(4.5)$ & $9(20.5)$ & $2(3.3)$ \\
$2012-2017$ & 126 & 65 & $61(48.4)$ & 5 & $3(2.4)$ & $2(\%)$ \\
\hline
\end{tabular}

Odonto: odontogenic

Table 6. Treatment outcome of odontogenic sinusitis according to the preoperative diagnostic accuracy

\begin{tabular}{lccc}
\hline Odonto sinusitis $(n=86)$ & Good:poor & Outcome $(\%)$ & p-value \\
\hline $\begin{array}{l}\text { Preoperative diagnosis } \\
(n=70)\end{array}$ & $68: 2$ & 97.1 & \\
$\begin{array}{l}\text { Missed diagnosis } \\
(n=16)\end{array}$ & $7: 9$ & 43.8 & 0.001 \\
\hline
\end{tabular}

Odonto: odontogenic

Table 7. Treatment outcome according cause of odontogenic sinusitis

\begin{tabular}{lccc}
\hline Odonto sinusitis $(n=86)$ & Good:poor & Outcome $(\%)$ & p-value \\
\hline $\begin{array}{l}\text { Periapical abscess } \\
(n=56)\end{array}$ & $46: 10$ & 82.1 & \\
Implant $(n=18)$ & $18: 0$ & 100.0 & 0.189 \\
Oroantral fistula $(n=12)$ & $11: 1$ & 91.7 & \\
\hline
\end{tabular}

Odonto: odontogenic

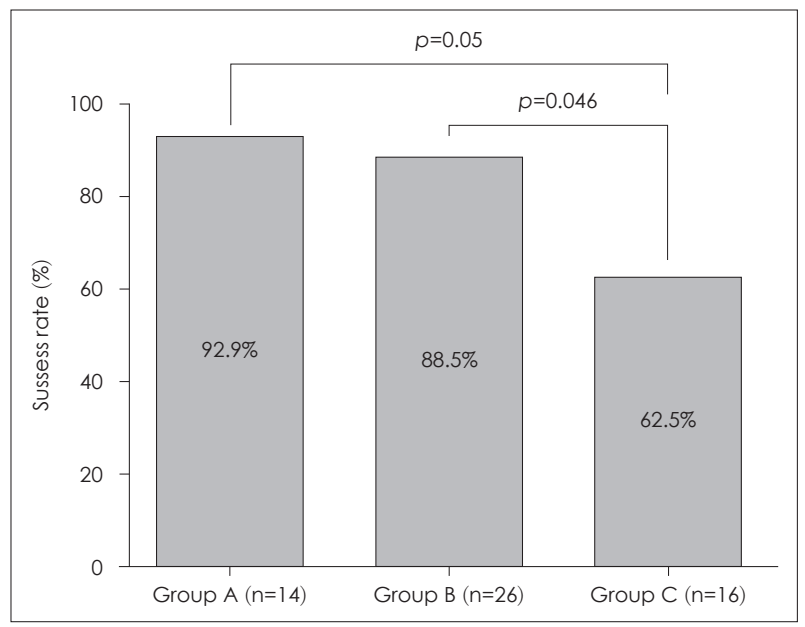

Fig. 2. Treatment outcomes according to the time point of dental treatment in cases of periapical abscess. Group $\mathrm{C}$ showed relatively lower success rates than group $A$ and $B$. There was a statistically significant difference in success rates between the $C$ and other groups (Mann-Whitney test: $p<0.05$ ). Group A: preoperative and intraoperative dental treatment group, Group B: postoperative dental treatment group, Group C: non-treated group.

\section{고 알려져 있다.}

과거에 비해 구강 위생 개선으로 치주 질환의 빈도는 감소 하였다. 하지만 임플란트 치료를 포함한 침습적 치과 시술이 급격히 늘어나면서 이로 인한 치성 부비동염의 발병률은 증 가하고 있는 추세이다. 2014년에 Lechien 등 ${ }^{18}$ 이 치성 부비 동염 환자를 대상으로 병인을 조사하였으며 674명의 환자 중
$65.7 \%$ 가 침습적인 치과 치료를 포함한 의인성 원인이었으며 치근염이 $25.1 \%$, 치주염이 $8.3 \%$ 를 차지하였다고 보고하였다. 또한 이 연구에서 조사한 치성 부비동염 원인 치아의 빈도를 보면 제 1 대구치가 $35.6 \%$ 으로 가장 많았고 그 뒤로 제 2 대구 치(22\%), 제3 대구치(17.4\%) 및 제2 소구치(14.4\%)순이었다. 제2 대구치가 상악동과 가장 근접해 있는 치아이지만 제 1 대 구치가 발치가 가장 많이 행해지기에 염증이 흔히 일어나는 부위로 알려져 있다.

치성 부비동염의 발병률에 대하여 최근 여러 문헌에서는 부비동염에서 $40 \%$ 정도가 치성 원인을 가지고 있다고 보고하 였다. 2018년에 스웨덴의 Goteborg 대학교 임상과학연구소 이비인후과에서 발표한 논문에서는 편측성 상악동 부비동염 환자 중 $48 \%$ 가 치성 부비동염으로 보고되었으며, 본 연구에 서도 총 195명 중 86명(44\%)가 치성 부비동염 환자로 비슷한 발병률을 보였다. ${ }^{19)}$ 또한 치성 부비동염은 40 60세 사이에서 가장 흔하다고 알려져 있으며 본 연구에서 치성 부비동염 환 자들의 평균 연령은 $52.7 \pm 14.5$ 로 기존 연구와 비슷한 수치를 보였다.

치성 부비동염의 임상적 증상은 일반적인 세균성 부비동염 에서 보이는 비폐색, 후비루, 안면부 압박감 및 압통, 후각 저 하의 증상과 더불어 치아의 염증으로 인한 치통 및 악취를 호 소하는 경우가 많다. 특히 악취는 세균학적 차이로 발생하게 된다. 치성 부비동염에서는 일반적으로 만성 부비동염에서 발 견되는 Streptococcus pneumonia나 Haemophilus influenza는 드물고 혐기성 세균이 자주 발견된다. ${ }^{20)}$ Bertrand 등 ${ }^{21)}$ 이 발표한 치성 부비동염에서 세균 동정에서는 주로 치아와 관련있는 Streptococcus, Streptococcus salivarius와 같은 호기성 세균과 Bacteroides, peptostreptococcus, fusobacterium과 같은 혐기성 세균이 동정되었다고 발표하였다. 본 연구에서도 치성 부비동염군이 비치성 부비동염군에 비하여 악취를 호소하는 환자들이 유의하게 많았고 이 역시 치성 부 비동염군과 비치성 부비동염군의 균의 차이로 인하여 나타 난 결과로 보인다.

2006년부터 2017년까지 12년간의 편측성 부비동염의 추 세를 보면 치성 부비동염의 유병률이 점점 증가하는 양상을 보였다. 이러한 치성 부비동염의 증가는 노인 인구와의 증가 와도 관련이 크다. 고령의 환자에서 면역력이 약하여 치과 질 
환이 부비동염으로 진행되는 경우가 많고, 임플란트와 같은 침습적인 치과 시술이 고령 환자들에게서 실시되는 경우가 많기 때문이다. 특히 노인 환자에서는 치아가 없는 경우 치경 부가 낮아지면서 함기화가 치근 사이로 진행되면서 피질 골 이 얇아지게 되어 임플란트와 같은 침습적 치과 시술에서 손 상 가능성이 높아진다. 또한 본 연구에서 과거에 치성 부비동 염 진단을 놓친 케이스가 많았던 것처럼 예전에는 치성 부비 동염에 대한 인식 부족으로 진단을 놓치는 경우가 많았지만 최근에 들어서는 치성 질환과 부비동염과의 연관성에 대한 관 심의 증대로 정확한 진단이 이루어지게 되는 것이 유병률 증 가에 영향을 주었다고 본다.

치성 부비동염 치료에서 중요한 점은 부비동염에 대한 외 과적, 내과적 치료뿐만 아니라 치성 원인에 대한 치료가 같 이 이루어져야 한다는 점이다. 본 연구에서는 치성 부비동염 환자 86명 중 75 명, $87.2 \%$ 에서 재발 및 합병증 없이 좋은 예후 를 유지하였다. 이 치료 성적은 2006년부터 2011년 군에서는 25명 중 16명으로 64\%의 낮은 수치에서 2012년부터 2017년 군의 61명에서 59명, 96.7\%으로 높은 증가를 보였다. 특히 치 성 부비동염 환자를 정확한 진단을 내린 그룹과 진단을 놓친 그룹 둘로 나누어서 치료 성적을 비교하면 치료 성적은 각각 $97.1 \%$ 와 $43.8 \%$ 으로 극명한 차이를 보였다. 즉, 치성 부비동 염 환자에서 정확한 진단을 내리게 되면 그에 맞는 적절한 치료로 이어져서 치료 성적이 향상된다고 생각할 수 있겠다.

반면에 본 연구에서 치성 부비동염 진단을 놓친 경우에는 절반 가량이 난치성 부비동염으로 진행되었다. 치주염이나 치 근염이 명확한 증상 없이 서서히 진행되는 경우에는 치과적 원인이 간과되기 쉽다. 치근염 치료 시 상악동 점막이 손상되 는 경우에 치과 치료에서 사용한 아말감 등과 같은 물질로 인 한 염증 반응이 일어나서 반복적인 상악동염을 유발하게 된 다. ${ }^{22)}$ 따라서 증상이 조절되지 않는 난치성 부비동염 환자에 서는 치과적인 증상이 명확하지 않더라도 영상의학적 검사와 병력 확인을 통하여 치성 원인을 감별해 보는 것이 중요할 것 이다.

치성 부비동염의 치료에 있어 부비동 내시경 수술과 치과 치료의 시기에 대한 명확한 프로토콜은 확립되어 있지 않다. 대부분 연구에서는 감염원을 제거하기 위하여 치과 치료를 먼저 시행한 후에 부비동 내시경 수술을 시행해야 한다고 제 안하였다. ${ }^{23)}$ 본 연구에서는 치성 부비동염 환자에서 치과 치 료를 받은 시기를 부비동 내시경 수술 전에 미리 받거나 입 원 시에 받은 군, 부비동 내시경 수술을 받은 이후에 외래 경 과 관찰을 하면서 차후에 치과 치료를 받은 군, 그리고 치과 치료를 받지 않은 군으로 나누어 성공률을 보았고, 치과 치료 를 받지 않은 군에서만 성공률이 $62.5 \%$ 로 두 군에 비해 유의
하게 낮았으며 치과 치료를 받은 두 군에서는 치과 치료 시점 과는 성공률과 유의한 연관성이 없었다. 이러한 본 연구의 결 과는 치성 부비동염에서 치과 치료를 반드시 먼저 시행할 필 요가 없다는 점을 시사한다. 치성 부비동염 환자의 치료에서 부비동 내시경 수술을 한 뒤에 외래 경과 관찰을 하면서 치 과 치료 시기를 정하는 방식으로도 치과 치료를 선행한 후 부 비동 내시경 수술을 시행하는 방식과 마찬가지로 좋은 치료 성적을 보일 것이라 생각된다.

이 연구의 한계점으로는 양측성을 제외한 일측성 부비동 염 환자와 일측성 치성 부비동염 환자만을 대상으로 한 점이 있겠다. 또한 치성 부비동염을 전산화단층촬영을 이용한 후 향적 방법으로만 진단하였고 정확한 병력과 이학적 검사는 이루어지지 않았기에 진단율에 오차가 발생할 수 있다는 점 이 있다. 그리고 비치성 부비동염과 치성 부비동염으로 나누 어 환자의 예후를 분석하였는데 수술 후 3 개월 시점으로 평 가하였기에 편측성 세균성 부비동염 환자의 좀 더 장기적인 예후에 대해서는 확인할 수가 없었다는 점이 있겠다.

그렇지만 기존에 치성 부비동염의 치료 가이드라인이 명확 하지 않으며 특히 치과 치료를 받는 시점에 대해서 명확하게 다룬 논문이 없었는데 본 연구에서 치과 치료 시점에 따라 예후를 비교하였고 이에 따라 치료 순서 프로토콜을 제시했 다는 점에서 가치가 있다고 생각한다. 특히 치료 순서에 있어 부비동 내시경 수술을 먼저 하고 환자를 외래에서 경과 관찰 을 하며 치과 치료 시기를 결정하는 방식으로 진행하게 되면 예후가 좋은 환자들에서는 침습적인 치과 치료를 할 필요가 적어지기에 치과 발치 치료를 먼저 한 뒤 내시경 수술을 하 는 방식보다는 치아를 좀 더 보존할 수 있는 장점이 있으리 라 생각된다.

\section{ORCID}

Young-Jun Chung https://orcid.org/0000-0002-3789-3485

\section{REFERENCES}

1) Rudralingam M, Jones $K$, Woolford TJ. The unilateral opaque maxillary sinus on computed tomography. $\mathrm{Br} \mathrm{J}$ Oral Maxillofac Surg 2002;40(6):504-7.

2) Ahsan F, El-Hakim H, Ah-See KW. Unilateral opacification of paranasal sinus CT scans. Otolaryngol Head Neck Surg 2005;133 (2):178-80.

3) Romashko AA, Stankiewicz JA. Routine histopathology in uncomplicated sinus surgery: Is it necessary? Otolaryngol Head Neck Surg 2005; 132(3):407-12; discussion 413.

4) Lee JY. Unilateral paranasal sinus diseases: Analysis of the clinical characteristics, diagnosis, pathology, and computed tomography findings. Acta Otolaryngol 2008;128(6):621-6.

5) Melén I, Lindahl L, Andréasson L, Rundcrantz H. Chronic maxillary sinusitis. Definition, diagnosis and relation to dental infections and nasal polyposis. Acta Otolaryngol 1986;101(3-4):320-7. 
6) Brook I. Sinusitis of odontogenic origin. Otolaryngol Head Neck Surg 2006;135(3):349-55.

7) Mehra P, Jeong D. Maxillary sinusitis of odontogenic origin. Curr Allergy Asthma Rep 2009;9(3):238-43.

8) Albu S, Baciut M. Failures in endoscopic surgery of the maxillary sinus. Otolaryngol Head Neck Surg 2010;142(2):196-201.

9) Lee KC, Lee SJ. Clinical features and treatments of odontogenic sinusitis. Yonsei Med J 2010;51(6):932-7.

10) Longhini AB, Ferguson BJ. Clinical aspects of odontogenic maxillary sinusitis: A case series. Int Forum Allergy Rhinol 2011;1(5):409-15.

11) Matsumoto Y, Ikeda T, Yokoi H, Kohno N. Association between odontogenic infections and unilateral sinus opacification. Auris Nasus Larynx 2015;42(4):288-93.

12) Troeltzsch M, Pache C, Troeltzsch M, Kaeppler G, Ehrenfeld M, Otto S, et al. Etiology and clinical characteristics of symptomatic unilateral maxillary sinusitis: A review of 174 cases. J Craniomaxillofac Surg 2015;43(8):1522-9.

13) Kim SW, Park YJ, Kim SW, Kang MG, Joo YH, Cho JH. A clinical analysis of fungal sinusitis. Korean J Otolaryngol-Head Neck Surg 2005;48(3):332-7.

14) Messerklinger W. Endoscopy of the nose. Baltimore: Urban and Schwarzenberg; 1978.

15) López-Carriches C, López-Carriches I, Bryan RB-P. Odontogenic sinusitis caused by an inflammation of a dentigerous cyst and subsequent finding of a fibrous dysplasia. A case report. Open Dent J 2016;10:647-55.
16) McCarty JL, David RM, Lensing SY, Samant RS, Kumar M, Van Hemert RL, et al. Root cause analysis: An examination of odontogenic origins of acute maxillary sinusitis in both immunocompetent \& immunocompromised patients. J Comput Assist Tomogr 2017;41 (3):484-8.

17) Zirk M, Dreiseidler T, Pohl M, Rothamel D, Buller J, Peters F, et al. Odontogenic sinusitis maxillaris: A retrospective study of 121 cases with surgical intervention. J Craniomaxillofac Surg 2017;45(4):520-5.

18) Lechien JR, Filleul O, Costa de Araujo P, Hsieh JW, Chantrain G, Saussez S. Chronic maxillary rhinosinusitis of dental origin: A systematic review of 674 patient cases. Int J Otolaryngol 2014; 2014:465173.

19) Ly D, Hellgren J. Is dental evaluation considered in unilateral maxillary sinusitis? A retrospective case series. Acta Odontol Scand 2018;76(8): $600-4$.

20) Lin PT, Bukachevsky R, Blake M. Management of odontogenic sinusitis with persistent oro-antral fistula. Ear Nose Throat J 1991; 70(8):488-90.

21) Bertrand B, Rombaux P, Eloy P, Reychler H. Sinusitis of dental origin. Acta Otorhinolaryngol Belg 1997;51(4):315-22.

22) Selmani $Z$, Ashammakhi N. Surgical treatment of amalgam fillings causing iatrogenic sinusitis. J Craniofac Surg 2006;17(2):363-5.

23) Mattos JL, Ferguson BJ, Lee S. Predictive factors in patients undergoing endoscopic sinus surgery for odontogenic sinusitis. Int Forum Allergy Rhinol 2016;6(7):697-700. 